\title{
MEDIASI SEBAGAI ALTERNATIF PENYELESAIAN SENGKETA KESEHATAN
}

Mansyur

Fakultas Hukum Universitas Borneo Tarakan

Email: pkbhubt@yahoo.com

\begin{abstract}
Abstrak.
Pelayanan kesehatan kepada masyarakat rentan menimbulkan sengketa kesehatan antara lemabaga penyedia layanan kesehatan seperti rumah sakit, dokter/dokter gigi dan perawat dengan pasien atau keluarganya. Penyelesaian sengketa kesehatan dapat dilakukan melalui peradilan baik melalui peradilan pidana maupun peradilan perdata.Disamping itu penyelesaian sengketa kesehatan juga dapat dilakukan melalui lembaga mediasi

Lembaga mediasi sebagai alternatif penyelesaian sengketa kesehatan apabila memenuhi kriteria sebagai berikut: Sengketa kesehatan yang terkait pada pelayanan kesehatan yang diterima atau berhubungan langsung dengan pasien, Sengketa kesehatan yang termasuk dalam katagori pelanggaran disiplin kedokteran Bukan termasuk sebagai sebuah tindak pidana, dan berdasarkan kehendak para pihak untuk memilih lembaga mediasi sebagai upaya penyelesaian sengketa dan dilakukan dengan iktikad baik. Hasil kesepakatan para pihak dituangkan dalam sebuah $\mathrm{k}$ akta tertulis mempunyai kekuatan mengikat sebagai sebuah perjanjian bagi para pihak..dan wajib didaftarkan di Pengadilan Negeri dengan mengajukan gugatan untuk ditetapkan dalam akta perdamaian oleh hakim Pengadilan Negeri setempat.

Kata Kunci; Mediasi, Sengketa, Kesehatan
\end{abstract}

\section{Abstract}

Health services to vulnerable communities cause health disputes between health care providers such as hospitals, doctors / dentists and nurses with patients or their families. Health dispute resolution can be done through the court either through criminal justice or civil court. Beside that, the dispute of health dispute can also be done through mediation institution

Mediation institution as an alternative dispute of health disputes if it meets the following criteria: Health disputes related to health services received or directly related to the patient, Health disputes included in the category of medical discipline violation Not included as a crime, and based on the will of the parties to choose a mediation institution as an attempt to resolve the dispute and be done with good faith. The result of the parties' agreement is set forth in a written certificate of having a binding force as an agreement for the parties .. and shall be 
registered in the District Court by filing a lawsuit to be stipulated in the peace certificate by the local District Court judge.

Keywords; Mediation, Dispute, Health

\section{PENDAHULUAN}

Kesehatan merupakan hak asasi manusia dan salah satu unsur kesejahteraan yang harus diwujudkan sesuai dengan cita-cita bangsa Indonesia sebagaimana dimaksud dalam Pancasila dan Undang-Undang Dasar Negara Republik Indonesia Tahun 1945. Penyelenggaraan upaya kesehatan harus dilakukan oleh tenaga kesehatan yang bertanggung jawab, yang memiliki etik dan moral yang tinggi, keahlian, dan kewenangan yang secara terus menerus harus ditingkatkan mutunya melalui pendidikan dan pelatihan berkelanjutan, sertifikasi, registrasi, perizinan, serta pembinaan, pengawasan, dan pemantauan agar penyelenggaraan upaya kesehatan memenuhi rasa keadilan dan perikemanusiaan serta sesuai dengan perkembangan ilmu pengetahuan dan teknologi kesehatan

Terkait dengan hal tersebut, masyarakat menuntut pelayanan kesehatan yang baik dari pihak rumah sakit, tetapi di sisi lain pemerintah belum dapat memberikan pelayanan sebagaimana yang diharapkan karena adanya keterbatasan- keterbatasan, kecuali rumah sakit swasta yang berorientasi bisnis sehingga dapat memberikan pelayanan kesehatan yang lebih baik. Selain itu profesi kedokteran sebagai komponen penting dalam pelayanan kesehatan sering mendapat kritikan-kritikan yang cukup pedas dari berbagai lapisan masyarakat, beberapa media massa pun ikut mengangkat berita-berita ini sampai kepermukaan.64. Padahal sebenarnya seorang dokter dalam menjalankan tugasnya mempunyai alasan yang mulia, yaitu berusaha mempertahankan

\footnotetext{
64 Ninik Mariyanti,Malapraktek Kedokteran Dari Segi Hukum Pidana dan Perdata, Bina Aksara,Jakarta, 1988, h 5.
} 
supaya tubuh pasien tetap sehat atau berusaha untuk menyehatkan tubuh pasien, atau setidak- tidaknya berbuat untuk mengurangi penderitaan pasien ${ }^{65}$

Meningkatnya sorotan masyarakat terhadap profesi kedokteran disebabkan adanya berbagai perubahan antara lain kemajuan teknologi informasi dan perkembangan hukum yang menyebabkan masyarakat semakin menyadari akan hak- haknya. Selain itu, terdapat suatu pergeseran paradigma, dimana hubungan antara dokter dan pasien yang dulunya menganut pola paternalistik berubah menjadi hubungan yang bersifat kontraktual. Kondisi dan situasi saat ini telah menempatkan dokter dalam peran sebagai pelaku ekonomi yakni sebagai penyedia layanan jasa. Sehingga, apabila jasa yang diberikan tidak memuaskan pasien, maka pasien pun berhak untuk menyampaikan keluhan bahkan sampai pada tuntutan hukum ke pengadilan ${ }^{66}$. Pemicu terjadinya sengketa adalah kesalahpahaman, perbedaan penafsiran, ketidak-jelasan pengaturan, ketidakpuasan, ketersinggungan, kecurigaan, tindakan yang tidak patut, curang atau tidak jujur, kesewenang-wenangan atau ketidakadilan, dan terjadinya keadaan yang tidak terduga

Sengketa kesehatan dalam hukum dikenal juga dengan istilah malpraktik. Sebenarnya dari asal katanya malpraktik tidak hanya ditujukan pada profesi kesehatan saja tetapi juga profesi pada umumnya, namun setelah secara umum mulai digunakan di luar negeri maka istilah itu sekarang diasosiasikan atau ditujukan pada profesi kesehatan. Pengertian malpraktik adalah any professional misconduct or unreasonable lack of skill or fidelity in professional or fiduciary duties, evil practice or illegal or immoral conduct. ${ }^{67}$

Kesenjangan persepsi dan kepentingan antara masyarakat dan pihak kedokteran sering berujung pada tuntutan dan gugatan hukum. Pada umumnya

\footnotetext{
65 Bahder Johan Nasution, Hukum Kesehatan Pertanggungjawaban Dokter,Rineka Cipta,Jakarta,2005,h. 23.

${ }^{66}$ H. Achmad Arman Subijanto, Peran Komunikasi Dalam Menjalankan Profesi Dokter Yang Berkualitas di Masyarakat, tersedia di hhttp /pustaka.uns.ac.id,diakses tanggal 24 Mei 2016.

${ }^{67}$ Black’s Law Dictionary, 7 ed. Minnesota: West Publishing Company; 1999.
} 
semua gugatan dan tuntutan hukum tersebut berawal dari fakta atau keadaan kesehatan yang dialami pasien yang bersangkutan pasca menjalani pengobatan dan sbagian besar disebabkan karena buruknya komunikasi yang tercipta antara health provider terhadap health receiver. Hingga tak jarang ketidakpuasan tersebut kemudian berujung pada tuntutan dan/atau gugatan hukum dari health receiver

Dalam praktek kedokteran yang selama ini apabila terjadi sengketa antara dokter dan pasien maka penyelesaian sengketa kesehatan tersebut akan diselesaikan melalui cara-cara sebagai berikut:

1. Perdamaian sengketa; yang dalam istilah kedokteran digunakan istilah penyelesaian dengan tali kasih, yang dilakukan oleh pihak rumah sakit sebagai institusi dimana dokter bekerja dengan pasien dan keluarganya;

2. Mengadukan permasalahan ke Majelis Kehormatan Disiplin Kedokteran Indonesia MKDKI , sesuai dengan ketentuan Pasal 66 Undang-Undang Nomor 29 Tahun 2004 tentang Praktek Kedokteran;

3. Melalui pengadilan dengan prosedur beracara sesuai Hukum Acara Perdata maupun tuntutan pidana melalui pihak kepolisian dan hukum acara pidana.

Salah satu bentuk penyelesaian sengketa kesehatan secara damai adalah mediasi. Mediasi merupakan suatu proses penyelesaian sengketa dengan pendekatan musyawarah untuk mencapai suatu kesepakatan perdamaian guna mengakhiri sengketa yang ada dengan dibantu oleh pihak ke-3 yang bersifat netral. Penyelesaian sengketa melalui proses mediasi telah diakui dalam hukum positif Indonesia, hal ini dapat kita lihat dalam Peraturan Mahkamah Agung RI nomor 1 tahun 2016 tentang Prosedur Mediasi Di Pengadilan, dimana secara tegas disebutkan bahwa semua sengketa perdata wajib dilakukan mediasi terlebih dahulu sebelum dilakukan proses persidangan. Dalam hal sengketa kesehatan, Undang Undang Kesehatan Nomor 36 tahun 2009 juga mewajibkan untuk dilakukan mediasi terlebih dahulu bila terjadi sengketa dalam pelayanan 
kesehatan.Namun minimnya penjelasan dan sosialisasi keberadaan lembaga ini di dalam upaya penyeleseaian sengketa medis ternyata telah melahirkan banyak permasalahan seperti bagaimana proses mediasi yang harus dilakukan, siapakah yang berwenang menjadi mediator dan bagaimana kekuatan hukum keputusan lembaga tersebut dan sebagainya dan sebagainya. Kondisi ini pun diperparah dengan rendahnya/minimnya kesadaran masyarakat dalam memahami fungsi, peranan dan proses beracara melalui lembaga mediasi ini. Karena sebagai bagian dari sistem hukum yang lebih besar, keberadaan lembaga mediasi ini pun seharusnya mampu berfungsi sebagai pengayom dan pelindung masyarakat dalam berkehidupan berbangsa dan bernegara yang berkeadilan, sehingga dapat tercapai tujuan akhir pembangunan kesehatan itu sendiri yakni terwujudnya derajat kesehatan masyarakat yang setinggi-tingginya sebagai bagiand ari investasi pembangunan sumber daya manusia Indonesia yang produktif secara sosial dan ekonomis.

Berdasarkan latar belakang di atas, maka dalam makalah ini penulis mencoba membatasi permasalahan sebagai berikut;

1. Penyelesaian sengketa hukum dalam pelayanan kesehatan

2. Kekuatan hukum mediasi sebagai alternatif penyelesaian sengketa kesehatan

\section{PEMBAHASAN}

\section{Penyelesaian Sengketa Hukum Dalam Pelayanan Kesehatan}

Hubungan antara dokter dengan pasien merupakan hubungan antara subjek hukum dengan subjek hukum dimana masing-masing pihak mempunyai hak dan kewajiban yang sama dalam menjalin komunikasi dan interaksi dua arah. Hukum memberikan perlindungan kepada kedua belah pihak melalui perangkat hukum yang disebut informed consent. Objek dalam hubungan hukum tersebut adalah pelayanan kesehatan kepada pasien. Dikaitkan dengan Undang- 
Undang Praktik Kedokteran, perangkat hukura informed consent tersebut diarahkan untuk

1. Menghormati harkat dan martabat pasien melalui pemberian informasi dan persetujuan atas tindakan yaang akan dilakukan.

2. Meningkatkan kesadaran, kemauan dan kemampuan hidup sehat

3. Menumbuhkan sikap positif dan itikad baik serta profesionalisme pada peran dokter/dokter gigi, mengingat pentingnya harkat dan martabat pasien.

4. Memelihara dan meningkatkan mutu pelayanan sesuai standar dan persyaratan yang berlaku

Dalam hubungannya dengan pasien, rumah sakit menawarkan upaya pelayanan kesehatan dengan menyediakan sarana, prasarana, dan sumber daya kesehatan, sedangkan bagi seseorang yang memerlukan pengobatan dapat memperoiehnya di rumah sakit. Rumah sakit memikul beban tanggung gugat apabila pelayanan kesehatan yang diberikan tidak memenuhi standar pelayanan di rumah sakit dan standar profesi tenaga kesehatan. Dengan demikian, kewajiban memenuhi standar profesi tidak semata menjadi tugas tenaga kesehatan pemberi layanan kesehatan yang secara langsung berinteraksi dan berperan dalam penyembuhan pasien, tetapi juga menjadi tugas rumah sakit untuk menjamin dilaksanakaimya standar tersebut oleh tenaga kesehatan yang bekerja di dalanmya. Standar pelayanan rumah sakit, berkaitan dengan kemampuan rumah sakit memberikan layanan kesehatan sesuai dengan kuaJifikasinya.

Dalam praktek pelayanan kesehatan tidak selalu bisa memberikan hasil sebagaimana yang diharap oleh pasien atau keluarga pasien, kesenjangan inilah yang sering menjadikan ketidakpuasan sehingga timbul sengketa kesehatan. Sengketa kesehatan jika dilihat dari periodenya bisa muncul dalam periode pra perawatan, saat perawatan maupun paska perawatan, begitu juga kalau kita 
lihat dari areanya bisa muncul pada ranah kode etik, disiplin kedokteran maupun, ranah yuridis.

Berlakunya norma etika dan norma hukum dalam pelayanan kesehatan. Di dalam setiap profesi termasuk profesi tenaga medis berlaku norma etika dan norma hukum. Oleh sebab itu apabila timbul dugaan adanya kesalahan praktek sudah seharusnyalah diukur atau dilihat dari sudut pandang kedua norma tersebut. Kesalahan dari sudut pandang etika disebut ethical malpractice dan dari sudut pandang hukum disebut yuridical malpractice. Hal ini perlu difahami mengingat dalam pelayanan kesehatan berlaku norma etika dan norma hukum, sehingga apabila ada kesalahan praktek perlu dilihat domain apa yang dilanggar. Karena antara etika dan hukum ada perbedaan-perbedaan yang mendasar menyangkut substansi, otoritas, tujuan dan sangsi, maka ukuran normatif yang dipakai untuk menentukan adanya ethical malpractice atau yuridical malpractice dengan sendirinya juga berbeda. Yang jelas tidak setiap ethical malpractice merupakan yuridical malpractice akan tetapi semua bentuk yuridical malpractice pasti merupakan ethical malpractice

Pada Lembaga pemberi layanan kesehatan seperti rumah sakit, sengketa yang terjadi pada pra perawatan dapat terjadi pada saat penerimaan awal (pendaftaran, Kegawat Daruratan), biasanya terjadi karena pelayanan yang tidak bisa ramah atau cepat, waktu menunggu yang lama berakibat pasien/keluarga merasa diterlantarkan, Pada periode perawatan biasanya diakibatkan oleh tenaga kesehatan yang tidak bisa memberikan komunikasi yang efektif karena kesibukan/banyak pasien, ada kecenderungan tidak menempatkan pasien pada posisi yang simetris tapi lebih pada posisi patronklien, sedang sengketa pasca perawatan bisa muncul karena pembiayaan yang besar, hasil dari perawatan yang tidak sesuai dengan harapan atau munculnya efek samping atau resiko medis lainnya.

Berkaitan dengan pelaksanaan pelayanan kesehatan, bila pasien atau keluarganya menganggap dokter telah melakukan perbuatan melawan hukum, 
pasien atau keluarganya dapat mengajukan tuntutan ganti rugi. Setiap orang juga beiliak untuk menggugat kerugian perdata ke pengadilan, hal ini sesuai dengan Pasal 66 butir 3 UU Praktik Kedokteran. Oleh karena itu bentuk upaya hukum yang dapat ditempuh oleh pasien bilamana pasien dirugikan karena tindakan medik yang tidak sesuai dengan yang diperjanjikan sebelumnya, berupa upaya hukum pidana (Criminal malpractice), dan upaya hukum perdata.(Civil malpractice). Penyelesaian hukum terhadap Criminal malpractice maupun Civil malpractice dilakukan melalui pengadilan. Disamping itu Undangundang juga mengatur mengenai penyelesaian sengketa kesehatan melalui penyelesaian alternatif (Alternative Dispute Resolutin) salah satunya adalah mediasi.

Pelayanan kesehatan dapat dimasukkan dalam kategori criminal malpractice manakala perbuatan tersebut memenuhi rumusan delik pidana yakni :

a. Perbuatan tersebut (positive act maupun negative act) merupakan perbuatan tercela.

b. Dilakukan dengan sikap batin yang salah (mens rea) yang berupa kesengajaan (intensional), kecerobohan (reklessness) atau kealpaan (negligence).

1) Criminal malpractice yang bersifat sengaja (intensional) misalnya melakukan euthanasia (pasal 344 KUHP), membuka rahasia jabatan (pasal 332 KUHP), membuat surat keterangan palsu (pasal 263 KUHP), melakukan aborsi tanpa indikasi medis pasal 299 KUHP).

2) Criminal malpractice yang bersifat ceroboh (recklessness) misalnya melakukan tindakan medis tanpa persetujuan pasien informed consent.

3) Criminal malpractice yang bersifat negligence (lalai) misalnya kurang hati-hati mengakibatkan luka, cacat atau meninggalnya pasien. 
Pertanggung jawaban didepan hukum pada criminal malpractice adalah bersifat individual/personal dan oleh sebab itu tidak dapat dialihkan kepada orang lain atau kepada rumah sakit/sarana kesehatan.

Seorang tenaga kesehatan akan disebut melakukan civil malpractice apabila tidak melaksanakan kewajiban atau tidak memberikan prestasinya sebagaimana yang telah disepakati (ingkar janji). Tindakan tenaga kesehatan yang dapat dikategorikan civil malpractice antara lain:

a. Tidak melakukan apa yang menurut kesepakatannya wajib dilakukan.

b. Melakukan apa yang menurut kesepakatannya wajib dilakukan tetapi terlambat melakukannya.

c. Melakukan apa yang menurut kesepakatannya wajib dilakukan tetapi tidak sempurna.

d. Melakukan apa yang menurut kesepakatannya tidak seharusnya dilakukan.

Pertanggung jawaban civil malpractice dapat bersifat individual atau korporasi dan dapat pula dialihkan pihak lain berdasarkan principle of vicarius liability. Dengan prinsip ini maka rumah sakit/sarana kesehatan dapat bertanggung gugat atas kesalahan yang dilakukan karyawannya (tenaga kesehatan) selama tenaga kesehatan tersebut dalam rangka melaksanakan tugas kewajibannya. mengusulkan diterapkannya pembuktian terbalik bagi kepentingan pasien. Cara lain untuk menyelesaikan masalah ini adalah dengan menggunakan doktrin Res ipsa loquitor. Titik tolak doktrin itu adalah: The thing speaks for it self yaitu fakta-fakta sudah berbicara sendiri sehingga tidak perlu dibuktikan lagi.

Penyelesaian sengketa ini seharusnya dilakukan secara berjenjang, mengingat profesi tenaga kesehatan atau lembaga yang menaunginya ini rentan terhadap pembunuhan karakter oleh media massa atau rentan terhadap pemerasan oleh oknum yang tak bertanggungjawab. 
Pada tataran pertama, bila gejala sengketa terbuka mulai muncul (surat ketidakpuasan hanya ditujukan ke pihak RS), sebaikanya pihak rumah sakit melalui bagian humas segera melakukan pendeketan guna menjawab atau klarifikasi terhadap permasalahan yang ada sehingga pihak pengadu/pelapor merasa puas dan terselesaikan permasalahannya. Pada tataran ke-2 bila sengketa

\section{Kekuatan Hukum Mediasi Sebagai Alternatif Penyelesaian Sengketa Kesehatan}

Proses penanganan tindakan medis tidak dipungkiri bisa menimbulkan sengketa Sengketa kesehatan adalah sengketa yang terjadi antara pasien atau keluarga pasien dengan tenaga kesehatan atau antara pasien dengan rumah sakit / fasilitas kesehatan. Biasanya yang dipersengketakan adalah hasil atau hasil akhir pelayanan kesehatan dengan tidak memperhatikan atau mengabaikan prosesnya. Padahal dalam hukum kesehatan diakui bahwa tenaga kesehatan atau pelaksana pelayanan kesehatan saat memberikan pelayanan hanya bertanggung jawab atas proses atau upaya yang dilakukan (Inspanning Verbintennis) dan tidak menjamin/ menggaransi hasil akhir (Resultalte Verbintennis).

Biasanya pengaduan dilakukan oleh pasien atau keluarga pasien ke instansi kepolisian dan juga ke media massa. Akibatnya sudah dapat diduga pers menghukum tenaga kesehatan mendahului pengadilan dan menjadikan tenaga kesehatan sebagai bulan-bulanan, yang tidak jarang merusak reputasi nama dan juga karir tenaga kesehatan ini. Sementara itu pengaduan ke kepolisian baik di tingkat Polsek, Polres maupun Polda diterima dan diproses seperti layaknya sebuah perkara pidana. Menggeser kasus perdata ke ranah pidana, penggunaan pasal yang tidak konsisten, kesulitan dalam pembuktian fakta hukum serta keterbatasan pemahaman terhadap seluk beluk medis oleh para penegak hukum di hampir setiap tingkatan menjadikan sengketa medik terancam terjadinya disparitas pidana. . 
Penyebab sengketa kesehatan ini bisa timbul dari ketidakpuasan pasien atas tindakan medis yang dilakukan oleh dokter dalam melaksanakan upaya pengobatan. Ketidakpuasan tersebut bisa semakin memanas dikarenakan adanya dugaan kelalaian dan kesalahan (perbuatan melanggar/malpraktek medis) dalam tindakan medis sehingga pasien mendapat kerugian dari aspek kesehatan

Selain itu sengketa yang terjadi antara dokter dengan pasien biasanya disebabkan oleh kurangnya informasi dari dokter, padahal informasi mengenai segala sesuatu yang berhubungan dengan tindakan medis yang dilakukan oleh dokter merupakan hak pasien, hal tersebut terjadi karena pola paternalistik yang masih melekat dalam hubungan tersebut. Upaya penyelesaian sengketa melalui peradilan umum yang selama ini ditempuh tidak dapat memuaskan pihak pasien, karena putusan hakim dianggap tidak memenuhi rasa keadilan pihak pasien. Hal ini disebabkan sulitnya pasien atau Jaksa Penuntut Umum maupun Hakim untuk membuktikan adanya kesalahan dokter. Kesulitan pembuktian dikarenakan minimnya pengetahuan mereka mengenai permasalahan-permasalahan tehnis sekitar pelayanan medik.

Adakalanya hubungan dokter dengan pasien tidak selalu berjalan dengan baik. Terkadang harapan pasien untuk mendapatkan kesembuhan dari penyakit yang dideritanya tidak terpenuhi dan bisa jadi justru memperparah kondisi tubuhnya, bahkan dapat menimbulkan kematian. Pasien atau keluarganya kemudian menganggap bahwa mungkin telah terjadi suatu kelalaian medik atau yang oleh media disebut dengan malpraktek medik. Walaupun setiap risiko pengobatan yang tidak diinginkan tidak dapat dikatakan sebagai malpraktik medik (Anny Isfandyarie), serta masih kaburnya ukuran malpraktik profesi kedokteran ( Agus Purwadianto), namun sebagai sebuah peristiwa hukum, malpraktik medik telah banyak terjadi di Indonesia, baik seperti yang ramai diberitakan media massa, yang sedang atau telah melakukan upaya hukum di pengadilan, atau hanya didiamkan saja oleh para pihak yang berkepentingan. 
Bagi pihak dokter atau sarana pelayanan kesehatan, penyelesaian sengketa medik melalui pengadilan / secara litigasi berarti mempertaruhkan reputasi yang telah dicapainya dengan susah payah, dan dapat menyebabkan kehilangan nama baik. Meskipun belum diputus bersalah atau bahkan putusan akhir dinyatakan tidak bersalah, nama baik dokter atau sarana pelayanan kesehatan sudah terkesan jelek karena sudah secara terbuka di media diberitakan telah diduga melakukan kesalahan dan akan menjadi stigma yang jelek pula dalam masyarakat yang pada gilirannya menyebabkan tingkat kepercayaan masyarakat terhadap dokter atau sarana pelayanan kesehatan tersebut akan turun.

Penyelesaian sengketa yang dianggap ideal bagi para pihak adalah penyelesaian yang melibatkan para pihak secara langsung sehingga memungkinkan dialog terbuka, dengan demikian keputusan bersama kemungkinan besar dapat tercapai. Disamping itu karena pertemuan para pihak bersifat tertutup maka akan memberikan perasaan nyaman, aman kapada para pihak yang terlibat sehingga kekhawatiran terbukanya rahasia dan nama baik yang sangat dibutuhkan oleh dokter maupun sarana pelayanan kesehatan dapat dihindari.

Dalam Pasal 66, :Undang-undang Nomor Nomor 29 Tahun 2004 Tentang Praktik Kedokteran

Ayat (1): Setiap orang yang mengetahui atau kepentingannya dirugikan atas tindakan dokter atau dokter gigi dalam menjalankan praktik kedokteran dapat mengadukan secara tertulis kepada Ketua Majelis Kehormatan Disiplin Kedokteran Indonesia.

Dalam Undang-Undang Nomor 29 Tahun 2004 Pasal 66 ayat (1) tersebut, secara implisit dikatakan bahwa sengketa kesehatan adalah sengketa yang terjadi karena kepentingan pasien dirugikan oleh tindakan dokter atau dokter gigi yang menjalankan praktik kedokteran. Dengan demikian maka sengketa kesehatan merupakan sengketa yang terjadi antara pengguna pelayanan medik 
dengan pelaku pelayanan medik dalam hal ini antara pasien dan dokter berikut sarana kesehatan.

Keberadaan lembaga mediasi sebagai salah satu bentuk penyelesaian sengketa medis dapat dilihat di dalam UU Nomor 36 Tahun 2009 tentang Kesehatan khususnya Pasal 29 dan Penjelasannnya yang menyebutkan bahwa “ dalam hal tenaga kesehatan diduga melakukan kelalaian dalam menjalankan profesinya, kelalaian tersebut harus diselesaikan terlebih dahulu melalui mediasi." Sementara di dalam Penjelasan menyebutkan alasan dan tujuan dilakukannya mediasi yakni bahwa mediasi dilakukan bila timbul sengketa antara tenaga kesehatan dengan pasien, dimana mediasi tersebut dilakukan dengan tujuan untuk menyelesaikan sengketa di luar pengadilan yang dilakukan oleh mediator yang disepakati oleh para pihak yang bersengketa.

Sementara di dalam UU Nomor 44 Tahun 2009 tentang Rumah Sakit tidak menyebutkan secara eksplisit tentang lembaga mediasi sebagai lembaga penyelesaian sengketa medis, namun di dalam Pasal 60 yang mengatur tentang tugas Badan Pengawas Rumah Sakit Provinsi disebutkan adanya kewenangan BPRS Provinsi ini untuk melakukan upaya penyelesaian sengketa melalui jalan mediasi. Hal ini berarti bahwa sengekta medis yang terjadi di rumah sakit pun diupayakan untuk ditempuh melalui jalan mediasi. Hal ini didasari pemikiran bahwa sebagian besar sengketa medis terjadi di sebuah rumah sakit, sebagai institusi penyelenggara pelayanan kesehatan/kedokteran yang dilakukan oleh tenaga kesehatan termasuk dokter/dokter gigi.

Keberadaan lembaga mediasi sebagai lembaga penyelesaian sengketa di luar pengadilan diakui di dalam UU Nomor 30 Tahun 1999 di dalam Pasal 1 ayat 10 yang menyebutkan bahwa APS adalah lembaga penyelesaia sengketa atau beda pendapat melalu prosedur yang disepakati para pihak yakni penyelesaian di luar pengadilan dengan cara konsultasi, negosiasi, mediasi, konsiliasi, atau penilaian ahli. Apabila lembaga arbitrase merupakan lembaga yang ditetapkan sebagai lembaga penyelesaiaan sengketa khusus di bidang perdagangan dan 
mengenai hak yang menurut hukum dan peraturan perundang-undangan dikuasasi sepenuhnya oleh pihak yang bersengketa (Pasal 5 UU APS), maka lembaga mediasi mempunyai ruang lingkup yang lebih luas yakni seluruh sengketa atau beda pendapat di bidang hukum keperdataan, yang akan diselesaikan dengan didasarkan pada itikad baik para pihak dalam upaya penyelesaianya (Pasal 6 ayat (1) UU AAPS).

Selain itu, mediasi bisa juga dilakukan oleh MKDKI (Majelis Kehormatan Disiplin Kedokteran Indonesia) sebagai lembaga yang menjaga marwah kehormatan dokter/dokter gigi dalam menjalankan disiplin keilmuan kedokteran. Majelis ini merupakan lembaga otonom KKI (Konsil Kedokteran Indonesia) yang keberadaannya berdasarkan Pasal 1 ayat 14 UU No. 29 Tahun 2004 tentang Praktik Praktek Kedokteran. Tugas MKDKI adalah menegakkan aturan-aturan dan ketentuan penerapan keilmuan kedokteran dalam pelaksanaan pelayanan medis yang seharusnya diikuti oleh dokter dan dokter gigi. Oleh karena itu, MKDKI merupakan badan yang ditunjuk oleh KKI untuk menangani kasus-kasus dugaan pelanggaran disiplin kedokteran atau kedokteran gigi dan menetapkan sanksi dimana penyelesaian dilakukan secara mediasi.

Pelanggaran disiplin adalah pelanggaran terhadap aturan-aturan atau ketentuan penerapan keilmuan, yang pada hakekatnya dapat dikelompokkan dalam 3 hal, yakni:

1) Melaksanakan praktik kedokteran yang tidak kompeten,

2) Tugas dan tanggung jawab professional pada pasien tidak dilaksanakan dengan baik,

3) Berperilaku tercela yang merusak martabat dan kehormatan profesi kedokteran.

MKDKI dapat menangani perkara dugaan pelanggaran disiplin kedokteran dan kedokteran gigi berdasarkan Keputusan Konsil Kedokteran Indonesia No.17/KKI/KEP/VIII/2006 tentang Penegakaan Disiplin Profesi Kedokteran. Ketentuan pelanggaran disiplin juga dapat dilihat dalam buku 
tentang penyelenggaraan praktik kedokteran yang baik di Indonesia yang diterbitkan berdasarkan Keputusan Konsil Kedokteran Indonesia No.18/ KKI/KEP/IX/2006.

Berdasarkan uraian di atas sebenarnya proses mediasi merupakan upaya yang tepat dalam menyelesaikan sengketa medis antara dokter dan pasien kecuali dalam proses pidana murni seperti pelecehan seksual, pengungkapan rahasia kedokteran, aborsi serta kelalaian berat, keterangan palsu, penipuan dan lain-lain. Penyelesaian melalui jalur litigasi akan merugikan kedua belah pihak. Apalagi cukup sukar untuk memenuhi empat kriteria malpraktik medis, yaitu:

1. Adanya duty (kewajiban) yang harus dilaksanakan

2. Adanya dereliction/breach of that duty (penyimpangan kewajiban);

3. Terjadinya damage

4. Terbuktinya direct causal relationship antara pelanggaran kewajiban dengan kerugian.

Terkait dengan penggunaan mediasi sebagai lembaga penyelesaian sengketa kesehatan, John W. Head sebagaimana dikutip oleh Gatot Soemartono ${ }^{68}$ mediasi adalah suatu prosedur penengahan di mana seseorang bertindak sebagai "kendaraan" untuk berkomunikasi antara para pihak, sehingga pandanga nmereka yang berbeda atas sengketa tersebut dapat dipahami dan mungkin didamaikan, tetapi tanggung jawab utama tercapainya suatu perdamaian tetap berada di tangan para pihak sendiri. Sementara itu Takdir Rahmadi menjelaskan bahwa mediasi sebagai suatu proses penyelesaian sengketa antara dua pihak atau lebih melalui perundingan atau cara mufakat dengan bantuan pihak netral yang tidak memiliki kewenangan memutus, yang disebut dengan mediator ${ }^{69}$

68 Gatot Soemartono; Arbitrase dan Mediasi Di Indonesia; PT Gramedia Pustaka Utama; Jakarta, 2005, h. 119

69 Takdir Rahmadi; Mediasi, Penyelesaian Sengketa Melalui Pendekatan Mufakat; Rawali pers; Jakarta, 2010, h. 12. 
Mediasi dapat dijadikan sebagai langkah awal dalam menyelesaikan sengeketa medis dikarenakan beberapa alasan berikut ${ }^{70}$

1. Bahwa upaya penyembuhan yang dilakukan oleh dokter merupakan upaya penyembuhan yang didasarkan pada usaha yang maksimal dan ikhtiar (inspanningverbintenis);

2. Ruang lingkup kesehatan untuk membuktikan dugaan perbuatan melanggar (malpraktek kedokteran) bukanlah hal yang mudah namun harus dipelajari dan di analisis terlebih dahulu setiap perbuatan buruk (adverse event); dan

3. Tidak semua adverse event identik dengan malpraktek kedokteran.

Efek positif lainnya dari proses mediasi adalah hubungan dokter pasien akan tetap senantiasa terjaga dengan baik. Karena bagaimanapun kedua belah pihak memerlukan kepentingan yang sama meskipun dalam konteks dan tanggung jawabnya masing-masing. Meskipun demikian, mediasi memiliki kelemahan yaitu keterbatasan dukungan yuridis terhadap proses dan hasilnya, termasuk terhadap eksekusi perjanjian penyelesaian

Pelayanan kesehatan dilakukan berdasarkan keilmuan kedokteran, dan ilmu kedokteran bukanlah ilmu pasti layaknya matematik atau fisika yang hasilnya bisa dipastikan melalui perhitungan, oleh karena itu kadang hasil dari perawatan tidak membuahkan hasil penyembuhan sesuai dengan harapan pasien, misalnya penyakit tidak kunjung sembuh, penyakit berkembang menjadi parah, bahkan bisa jadi muncul efek samping lainnya dari pengobatan yang dilakukan. Mendasarkan pada alasan tersebut sebenarnya dugaan malpraktik yang sering dilaporkan sebenarnya bukanlah tindak pidana kejahatan karena tenaga kesehatan, dalam memberikan pengobatan semata-mata hanyalah untuk membantu dalam proses penyembuhan dan tidak mempunyai motivasi untuk mencelakakan/merugikan/menghilangkan nyawa orang lain sebagaimana

\footnotetext{
${ }^{70}$ http://www.lbhyogyakarta.org/2013/07/mediasi-non-litigasi-langkah-awal-penyelesaiansengketa-medis/
} 
sering kita temukan dalam poin laporan/tuntutan/gugatan perbuatan melawan hukum.

Penyelesaian sengketa yang saat ini banyak diketahui oleh masyarakat adalah melalui cara litigasi yaitu beracara di pengadilan, karakteristik penyelesaian sengketa melalui jalur litigasi adalah bersisifat terbuka, rigid yakni mengikuti prosedur formal beracara di pengadilan, otoritas ada dipengadilaan, diperlukan adanya pengacara, dan putusan berupa menang atau kalah, karakteristik ini tentu kurang tepat jika diterapkan pada sengketa kesehatan, karena pada umumnya inti pada sengketa kesehatan lebih pada permintaan dan pemberian penghargaan diri dari pasien, perbaikan pelayanan dari lembaga dan atau ganti rugi terhadap kelainan yang timbul dari suatu proses pelayanan kesehatan.

Mediasi merupakan bentuk alternative penyelesaian sengketa yang diakui oleh hokum dan lembaga penegak hukum di Indonesia, bahkan setiap sengketa yang masuk dalam pengadilan diharuskan untuk di mediasi terlebih dahulu sebelum masuk dalam proses peradilan, ketentuan ini diatur dalam Perma nomor 1 tahun 2008. Dalam hal penyelesaian sengketa kesehatan melalui mediasi, Pasal 29 Undang-Undang Kesehatan Nomor 36 tahun 2009 sebagai dapat dijadikan dasar hukum pelaksanaannya. Mediasi dalam penyelesaian sengketa kesehatan dibantu oleh pihak ketiga yang bersifat netral yang disebut Mediator. Untuk bisa menjadi mediator bersertifikat, seseorang harus mengikuti pendidikan mediator yang diselenggarakan oleh lembaga yang telah mendapatkan akreditasi dari Mahkamah Agung RI,

Mediasi yang selama ini ditempuh oleh pihak-pihak yang bersengketa dalam sengketa medik masih terkurung dalam masalah yang klasik, dimana sang mediator sangat terbatas pengetahuannya dibidang hukum maupun kesehatan. Melalui penelitian yang dilakukan sebelumnya, para pihak dalam sengketa medik seharusnya memiliki wadah khusus yang memang menangani khusus masalah medik dan ditangani oleh beberapa orang yang berkompeten dan ahli 
dibidang hukum dan kesehatan. Mediator yang menangani para pihak yang bersengketa memang menguasai hukum kesehatan yang terdiri dari banyak disiplin diantaranya hukum kedokteran dan/atau kedokteran gigi, hukum keperawatan, hukum farmasi klinik, hukum apotik, hukum kesehatan masyarakat, hukum perobatan, hukum rumah sakit, dan hukum kesehatan lingkungan. Perlu adanya suatu wadah yang memang menangani khusus sengketa medik, sehingga kelemahan-kelemahan dalam penyelesaian sengketa melalui litigasi dan juga beberapa dalam penyelesaian sengketa non litigasi dapat teratasi sehingga pasien tidak mengalami kesulitan dalam memerjuangkan haknya dan juga dirasa adil bagi profesi dokter dan/atau dokter gigi serta instasi rumah sakit. Adapun wadah tersebut nantinya terdiri dari anggota yang memang berkopenten dibidang hukum dan kesehatan untuk bisa membantu sengketa medik yang dialami pasien dengan dokter dan/atau dokter gigi serta rumah sakit. Wadah ini nantinya diciptakan dengan mempertimbangan kondisi pasien yang dalam sengketa medik berada dalam posisi yang lemah terkait faktor kesehatan, faktor psikologis, dan faktor ekonomi.

Mediator dengan menggunakan teknik bermediasi akan menjembatani dan memfasilitasi parapihak untuk menemukan titik tengah dalam rangka membuat perdamaian guna mengakhiri sengketa yang ada. Akhir dari proses mediasi adalah mediasi dinyatakan gagal atau berhasil. mediasi yang berhasil menghasilkan nota perdamaian untuk di implemetasikan oleh parapihak, atau sebelum diimplementasikan dapat dimintakan putusan dari hakim pengadilan menjadi akta perdamaian yang bersifat final dan binding dan bisa dilakukan eksekusi. Akta perdamainan yang dihasilkan dari proses mediasi memiliki kekuatan hukum yang tetap dan mengikat, tindak tunduk pada upaya hukum biasa, oleh karena itu tidak ada proses banding maupun kasasi

Pengembangan mediasi sebagai alternative penyelesaian sengketa mempunyai dasar hukum yang kuat yaitu Pasal 6 UU No.30 tahun 1999 tentang 
arbitrase dan Alternatif penyelesaian sengketa, Pasal 130 HIR/154 Rbg dan Peraturan Mahkamah Agung No.2 tahun 2003 yang disempurnakan dengan Peraturan Mahkamah Agung No.1 tahun 2008. Dalam penyelesaian sengketa kesehatan melalui proses mediasi di akomodir dalam ketentuan yang dikeluarkan oleh konsil kedokteran Indonesia begitu juga dalam UndangUndang Kesehatan Nomor 36 tahun 2009 pasal (29) "Dalam hal tenaga kesehatan diduga melakukan kelalaian dalam menjalankan profesinya, kelalaian tersebut harus diselesaikan terlebih dahulu melalui mediasi"

Metode mediasi merupakan alternatif penyelesaian sengketa yang dapat dipilih oleh dokter dengan pasien untuk menyelesaikan sengketa malpraktek medik karena mediasi merupakan suatu proses penyelesaian sengketa di antara para pihak dengan melibatkan pihak ketiga yang netral, walaupun sebenarnya ada alternatif penyelesaian sengketa yang lain yaitu konsiliasi yang mana di dalamnya ada pihak ketiga sebagai konsiliator yang terlibat dan bersifat netral, namun konsiliator hanyalah sebagai pihak fasilitator untuk melakukan komunikasi di antara para pihak sehingga dapat diketemukan solusi oleh para pihak sendiri, dengan demikian pihak konsiliator hanya melakukan tindakantindakan seperti mengatur waktu dan tempat pertemuan para pihak, mengarahkan subyek pembicaraan, membawa pesan dari satu pihak kepada pihak lain jika pesan tersebut tidak mungkin disampaikan langsung atau para pihak tidak mau bertemu muka langsung.

Mediasi, seorang mediator pun melakukan hal-hal yang dilakukan oleh konsiliator, tetapi juga melakukan lebih jauh dari itu, sebab pihak mediator dapat juga menyarankan jalan keluar atau proposal penyelesaian sengketa yang bersangkutan, paling tidak secara teoritis tidak ada dalam kewenangan pihak konsiliator.

Dengan demikian mediasi merupakan alternatif penyelesaian sengketa yang cukup efektif dan menguntungkan para pihak karena baik pihak pasien sebagai orang awam yang tidak mengetahui ilmu pengetahuan kedokteran 
maupun pihak dokter diberikan pengertian-pengertian oleh mediator mengenai hal-hal yang berkaitan dengan malpraktek medik, aspek-aspek hukum malpraktek medik, dan lain-lain yang diperlukan untuk penyelesaian sengketa tersebut, sehingga kedua belah pihak dapat menyelesaikan sengketanya sendiri

Penyelesaian sengketa dilakukan secara mediasi/ non litigasi/ penyelesaian di luar pengadilan maka hasil kesepakatan mediasi yang dilakukan oleh para pihak dituangkan dalam sebuah bentuk akta tertulis yang mempunyai kekuatan mengikat sebagai sebuah perjanjian bagi para pihak. Apabila ternyata salah satu pihak tidak melakukan kewajiban sesuai yang tercantum di dalam akta perdamaian mediasi tersebut, maka pihak lain yang merasa dirugikan dapat menempuh jalur litigasi dengan menggugat pihak yang melanggar isi perjanjian dengan gugatan wanprestasi berdasarkan Pasal 1234 KUHPerdata.

Kesepakatan penyelesaian sengketa atau beda pendapat yang dituangkan dalam akta tertulis tersebut adalah final dan mengikat para pihak untuk dilaksanakan dengan iktikad baik serta wajib didaftarkan di Pengadilan Negeri dengan mengajukan gugatan untuk ditetapkan dalam akta perdamaian oleh hakim Pengadilan Negeri setempat.

\section{PENUTUP}

Pelayanan kesehatan kepada masyarakat rentan menimbulkan sengketa kesehatan antara lemabaga penyedia layanan kesehatan seperti rumah sakit, dokter/dokter gigi dan perawat dengan pasien atau keluarganya. Penyelesaian sengketa kesehatan dapat dilakukan melalui peradilan baik melalui peradilan pidana maupun peradilan perdata.Disamping itu penyelesaian sengketa kesehatan juga dapat dilakukan melalui lembaga mediasi

Lembaga mediasi sebagai alternatif penyelesaian sengketa kesehatan apabila memenuhi kriteria sebagai berikut: 
a. Sengketa kesehatan yang terkait pada pelayanan kesehatan yang diterima atau berhubungan langsung dengan pasien. Dalam arti ada hubungan hukum antara pasien dan dokter.

b. Sengketa kesehatan yang termasuk dalam katagori pelanggaran disiplin kedokteran

c. Bukan termasuk sebagai sebuah tindak pidana yang secara tegas disebutkan dalam UU Kesehatan, UU Praktik Kedokteran dan KUHPidana

d. Berdasarkan kehendak para pihak untuk memilih lembaga mediasi sebagai upaya penyelesaian sengketa dan dilakukan dengan iktikad baik.

Penyelesaian sengketa dilakukan secara mediasi maka hasil kesepakatan para pihak dituangkan dalam sebuah bentuk akta tertulis mempunyai kekuatan mengikat sebagai sebuah perjanjian bagi para pihak. Apabila ternyata salah satu pihak tidak melakukan kewajiban sesuai yang tercantum di dalam akta perdamaian mediasi, maka pihak lain yang merasa dirugikan dapat menempuh jalur litigasi dengan menggugat pihak yang melanggar isi perjanjian dengan gugatan wanprestasi berdasarkan Pasal 1234 KUHPerdata.

Kesepakatan penyelesaian sengketa atau beda pendapat yang dituangkan dalam akta tertulis tersebut adalah final dan mengikat para pihak untuk dilaksanakan dengan iktikad baik serta wajib didaftarkan di Pengadilan Negeri dengan mengajukan gugatan untuk ditetapkan dalam akta perdamaian oleh hakim Pengadilan Negeri setempat.

\section{DAFTAR PUSTAKA}

Black's Law Dictionary, 7 ed. Minnesota: West Publishing Company; 1999.

Johan Nasution, Bahder, Hukum Kesehatan Pertanggungjawaban Dokter,Rineka Cipta,Jakarta,2005,

Mariyanti, Ninik, Malapraktek Kedokteran Dari Segi Hukum Pidana dan Perdata, Bina Aksara,Jakarta, 1988, 